\title{
Commercial preparations of pesticides exert higher toxicity and cause changes at subcellular level in earthworm Eisenia andrei
}

\author{
Carina Lackmann ${ }^{1,2}$, Mirna Velki $^{3}$, Dora Bjedov ${ }^{3}$, Sandra Ečimović ${ }^{3}$, Thomas-Benjamin Seiler ${ }^{2,4}$ \\ and Henner Hollert ${ }^{1,2,5^{*}}$ (B)
}

\begin{abstract}
Background: The environmental impact of pesticides has been an increasingly discussed issue over the last decades. Constant usage of pesticides presents a burden for soil and causes a decrease in its health, including the negative effects on earthworms which are indicators for soil quality. The objective of this research was the assessment of the effects of two insecticides and two herbicides on the earthworm Eisenia andrei. Namely, the following active ingredients and respective commercial preparations were investigated: esfenvalerate (Sumialfa), thiacloprid (Calypso), dimethenamid- $p$ (Frontier) and prosulfocarb (Filon). Lethal concentrations (48 h) of both active ingredient and commercial preparations were determined using the filter paper contact test.
\end{abstract}

Results: The results showed that Calypso and Frontier were significantly more toxic than the active ingredient. Therefore, all further measurements were performed after exposure of earthworms to the commercial preparations of the pesticides. Specifically, several enzymatic biomarkers and multixenobiotic resistance activity were assessed. Additionally, a fluorescence-based assay for the determination of oxidative stress was established. Significant changes were detected for catalase, carboxylesterase and multixenobiotic activities after 48-h exposures. Also, a significant change in oxidative stress parameters could be observed for both Calypso and Frontier.

Conclusions: The obtained results show that commercial preparations can be more toxic than the active ingredients, and the formulations being distributed in the environment can affect earthworms on a molecular level already after short exposures. This emphasizes the importance of a more integrated eco-toxicological assessment of commercial pesticide preparations not to underestimate their effects on the environment.

Keywords: Earthworms, Commercial pesticide preparations, Acute toxicity, Oxidative stress, Multixenobiotic resistance activity

\section{Background}

The environmental impact of pesticides has been an increasingly discussed issue over the last few decades [47]. Even though the awareness for sustainable and organic farming practices has risen continuously [14, 42],

\footnotetext{
*Correspondence: hollert@bio.uni-frankfurt.de

${ }^{1}$ Department of Evolutionary Ecology and Environmental Toxicology, Goethe University Frankfurt, Max-von-Laue-Str. 13, 60438 Frankfurt am Main, Germany

Full list of author information is available at the end of the article
}

the usage of pesticides has steadily increased worldwide [49]. Pesticides are chemical or biological agents used to control pests and vectors of disease. They belong to the group of chemicals intentionally brought into the environment, and therefore their applications need to be strictly regulated. However, in 2018, over 50 years after the release of Rachel Carson's Silent Spring, the German National Academy of Sciences Leopoldina released their discussion paper "The silent spring-on the need for sustainable plant protection" [47], concluding that current 
regulations and assessment strategies are not effective enough to avoid adverse effects on the environment. As more and more studies have associated biodiversity losses with pesticide usage, implementing more sustainable agricultural practices and improving current pesticide regulations becomes increasingly urgent in order to stay within the planetary boundaries [14, 19, 40,51]. While there are additional stressors such as climate change and environmental pollution [28, 47] which might contribute to some observed adverse effects, it is necessary to improve standard agricultural practices and include more detailed eco-toxicological data to better understand their impact as the usage of pesticides will likely not decrease in the near future.

With natural resources being finite and constantly decreasing due to misuse of land and mismanagement of soil, it is crucial to understand the negative effects pesticides might have on soil and help improving agricultural practices [8]. Soil is a non-renewable resource, therefore, sustainable agricultural practices need to focus on ensuring the quality and fertility of the soil. Earthworms have long been used as bioindicators for soil quality, as their abundance and species composition can give valuable information on the fertility of soil [17, 37, 39]. Overall, they are essential for the nutrient balance of soil and their burrowing improves the soil structure and helps to increase decomposition, humification, and nutrient cycling [25]. As a consequence, earthworms are crucial for maintaining soil properties such as water holding capacity, porosity, aeration and $\mathrm{pH}$ but also play an important role in increasing the habitat quality for various soil organisms, thus often being referred to as ecosystem engineers [1].

With the increase of extensive use of pesticides in the last decades, their potential adverse impact on soil communities became more apparent. Generally, pesticides can be classified by their target organism or their mode of action. Data of global pesticide usage show that herbicides made up the largest portion, while insecticides were the second biggest class of pesticides used worldwide in 2018 [16]. While insecticide disruptions of the nervous system are known to be problematic for many nontarget organisms such as, e.g., bees [10], the main mode of action of herbicides through targeting plant-specific mechanisms often suggests that they might not be toxic for animals. Research, however, has shown that this is not the case $[22,27,55$. Out of many pesticides available on the market, four pesticides used worldwide have been chosen for this study: the herbicides dimethenamid- $p$, a chloroacetamide, and prosulfocarb, a thiocarbamate, both inhibiting the long chain fatty acid synthesis [41] and the insecticides esfenvalerate, belonging to the class of synthetic pyrethroid which block sodium channels [46,
50], and thiacloprid, a neonicotinoid that stimulates the nicotinic acetylcholine receptor [32, 33]. Even though these four pesticides have been heavily used in Europe, e.g., in Germany domestic sales amounted to 250-1000 t of dimethenamid- $p$ and prosulfocarb, $<1 \mathrm{t}$ of esfenvalerate and 25-100 t thiacloprid, which has been on the substitution list of the European Union since 2015, with a decision in 2020 to not renew its approval anymore [5, 13], there is very scarce data on their adverse effects on soil non-target organisms.

Since all four pesticides are so far still in usage and hence a potential threat to the environment, in this research their effects and possible other modes of action were assessed. The earthworms Eisenia andrei has been chosen, due to its widespread use as a model organism for soil toxicology, also being recommended by the OECD in their test guidelines [36].

The objective of the present research was therefore to assess the effects of four commonly used pesticides on the earthworm $E$. andrei by applying the filter paper contact test. Previous studies often only determined the effects of the active ingredient [15] as current regulations only include the toxicity of the active ingredient. To investigate, whether there is a discrepancy between the acute toxicity, here the acute toxicity was assessed for both the active substance and the respective commercial preparations. Due to implications obtained from these results, further assessments of the specific mode of actions were performed for the commercial preparations only. These measurements included the assessment of the effects of sublethal pesticide concentrations on enzymatic activities and multixenobiotic resistance (MXR) activity. Multixenobiotic resistance is an important first line of defense to actively expel toxic substances from cells before they cause any cellular damage [2]. For the assessment of pesticide effects on enzymatic activities, both oxidative stress-related and detoxification enzymes were chosen to enable gaining insight into the modes of action and detection of early effects. Furthermore, an assay based on a previous study on zebrafish larvae $[26,27]$ was established for the fluorescence-based assessment of oxidative stress (reactive oxygen species and glutathione) in earthworms. The obtained results are thought to add to a more integrated eco-toxicological assessment of pesticides and their commercial preparations to not underestimate their effects on the environment.

\section{Material and methods \\ Chemicals}

The following chemicals (analytical grade) were used: acetonitrile $\left(\mathrm{C}_{2} \mathrm{H}_{3} \mathrm{~N}\right.$, CAS 75-05-8), $\beta$-nicotinamide adenine dinucleotide $2^{\prime}$-phosphate reduced tetrasodium salt hydrate ( $\beta$-NADPH) $\quad\left(\mathrm{C}_{21} \mathrm{H}_{26} \mathrm{~N}_{7} \mathrm{Na}_{4} \mathrm{O}_{17} \mathrm{P}_{3} \mathrm{xH}_{2} \mathrm{O}, \mathrm{CAS}\right.$ 2646-71-1 
(anhydrous)), 9-(2-carboxyphenyl)-6-diethylamino3-xanthenylidene]-diethylammonium chloride (rhodamine B) $\left(\mathrm{C}_{28} \mathrm{H}_{31} \mathrm{ClN}_{2} \mathrm{O}_{3}\right.$, CAS 81-88-9), CellTracker ${ }^{\mathrm{TM}}$ Green CMFDA Dye $\left(\mathrm{C}_{25} \mathrm{H}_{17} \mathrm{ClO}_{7}\right.$, CAS 136832-63-8) (ThermoFisher Scientific), 1-chloro-2,4-dinitrobenzene (CDNB) $\left(\mathrm{C}_{6} \mathrm{H}_{3} \mathrm{ClN}_{2} \mathrm{O}_{4}, \mathrm{CAS}\right.$ 97-00-7), CM- ${ }_{2}$ DCFDA $\left(\mathrm{C}_{27} \mathrm{H}_{19} \mathrm{Cl}_{3} \mathrm{O}_{8}\right.$, CAS 1219794-09-8) (ThermoFisher Scientific), hydrogen peroxide $\left(\mathrm{H}_{2} \mathrm{O}_{2}, \mathrm{CAS}\right.$ 7722-84-1), (2-mercaptoethyl)trimethylammonium iodide acetate (acetylthiocholine iodide) $\left(\mathrm{CH}_{3} \mathrm{COSCH}_{2} \mathrm{CH}_{2} \mathrm{~N}\left(\mathrm{CH}_{3}\right)_{3} \mathrm{I}\right.$, CAS 1866-15-5), disodium hydrogen phosphate $\left(\mathrm{NaH}_{2} \mathrm{PO}_{4}\right.$, CAS 7558-79-4), 5,5'-dithiobis-(2-nitrobenzoic acid) (DTNB) ([- $\left.-\mathrm{SC}_{6} \mathrm{H}_{3}\left(\mathrm{NO}_{2}\right) \mathrm{CO}_{2} \mathrm{H}\right]_{2}$, CAS 69-78-3), glutathione disulfide (GSSG) $\left(\mathrm{C}_{20} \mathrm{H}_{32} \mathrm{~N}_{6} \mathrm{O}_{12} \mathrm{~S}_{2}\right.$, CAS 2702541-8), 4-nitrophenyl acetate $\left(\mathrm{C}_{8} \mathrm{H}_{7} \mathrm{NO}_{4}\right.$, CAS 830-03-5), (2S)-2-amino-4-\{[(1R)-1-[(carboxymethyl)carbamoyl]2-sulfanylethyl]carbamoyl\}butanoic acid (glutathione (GSH)) $\left(\mathrm{C}_{10} \mathrm{H}_{17} \mathrm{~N}_{3} \mathrm{O}_{6} \mathrm{~S}\right.$, CAS 70-18-8), sodium dihydrogen phosphate dihydrate $\left(\mathrm{NaH}_{2} \mathrm{PO}_{4} \times 2 \mathrm{H}_{2} \mathrm{O}\right.$, CAS 13472-35-0). Pierce $^{\mathrm{TM}}$ BCA Protein Assay Kit was used for protein concentration measurements.

The following pesticide active ingredients (analytical standard) and respective commercial preparations were used in this study: dimethenamid- $p\left(\mathrm{C}_{12} \mathrm{H}_{18} \mathrm{ClNO}_{2} \mathrm{~S}\right.$, CAS 163515-14-8) (Frontier, BASF, $720 \mathrm{~g} / \mathrm{L}$ a.i.), esfenvalerate $\left(\mathrm{C}_{25} \mathrm{H}_{22} \mathrm{ClNO}_{3}\right.$, CAS 66230-04-4) (Sumialfa, Arysta LifeScience, $50 \mathrm{~g} / \mathrm{L}$ a.i. $)$, prosulfocarb $\left(\mathrm{C}_{14} \mathrm{H}_{21} \mathrm{NOS}\right.$, CAS 52888-80-9) (Filon, SYNGENTA, $800 \mathrm{~g}$ L a.i.), thiacloprid $\left(\mathrm{C}_{10} \mathrm{H}_{9} \mathrm{ClN}_{4} \mathrm{~S}\right.$, CAS 111988-49-9) (Calypso, Bayer Crop Science, $480 \mathrm{~g} \mathrm{~L}$ a.i.)

\section{Test organism}

All tests were performed using adult earthworms ( $E$. andrei) which were obtained prior to the experiments from a local supplier and acclimatized at $20{ }^{\circ} \mathrm{C}$. To prepare the earthworms for the experiment, adult individuals showing a well-developed clitellum were selected and thoroughly washed with distilled water before being placed on damp filter paper for $12 \mathrm{~h}$ to void their gut contents [36].

\section{Acute toxicity tests}

The filter paper contact test was performed according to the OECD Guideline 207 [36]. It allows the assessment of effects without potential interference from the soil matrix, while also being easy to perform and offering higher reproducibility [61].

Due to their poor water solubility the active ingredients were dissolved in acetone and the desired concentrations prepared. The respective solution $(2 \mathrm{~mL}$ of solution per vial) was then evenly distributed onto the filter paper in glass vial $(4.5 \mathrm{~cm}$ height and $6 \mathrm{~cm}$ diameter). The vials were then left open for the acetone to completely evaporate. Only then $2 \mathrm{~mL}$ distilled water per vial was evenly distributed on the filter paper and one earthworm per vial added. Afterwards, each vial was closed with a lid. Based on preliminary tests the following concentrations (covering full range of no effects to $100 \%$ mortality) for assessment of the acute toxicity of the active substances were applied: thiacloprid 100, 200, 400, 600, 800 and $1000 \mathrm{ng} / \mathrm{cm}^{2}$, esfenvalerate 20, 30, 40, 50 and $100 \mathrm{ng} / \mathrm{cm}^{2}$, dimethenamid- $p 2.5,5,7.5,10$ and $12.5 \mu \mathrm{g} /$ $\mathrm{cm}^{2}$ and prosulfocarb $1,5,7.5,10,12.5,20$ and $30 \mu \mathrm{g} /$ $\mathrm{cm}^{2}$. Controls were performed in parallel using the same procedure of applying $2 \mathrm{~mL}$ acetone and after evaporation adding $2 \mathrm{~mL}$ of distilled water per vial. The exposure vials were placed in the dark at $20^{\circ} \mathrm{C}$ and the mortality was recorded after $24 \mathrm{~h}$ and $48 \mathrm{~h}$. The exposures were performed in at least three independent replicates with 5 earthworms per each exposure condition and replicate.

The commercial preparations of the pesticides were diluted in distilled water to obtain the desired concentrations. Afterwards $2 \mathrm{~mL}$ of solution per vial were evenly distributed onto the filter paper in flat-bottom glass vials and further treated as described above. The following concentrations for assessment of the acute toxicity of the commercial preparations were applied for each pesticide based on preliminary tests: Calypso 10, 20, 40, 50, 60,70 and $80 \mathrm{ng} / \mathrm{cm}^{2}$, Sumialfa 12.5, 25, 50, 75, 100, 125, 250 and $500 \mathrm{ng} / \mathrm{cm}^{2}$, Frontier 1, 1.5, 2.25, 2.5, 2.75, 3 and $5 \mu \mathrm{g} / \mathrm{cm}^{2}$ and Filon $1,1.25,2.5,5,7.5,10,12.5,15,20$ and $25 \mu \mathrm{g} / \mathrm{cm}^{2}$. Concentrations of commercial preparations are expressed as amounts of active substance in the formulation. Controls with distilled water only were also performed. The exposure vials were then placed in the dark at $20{ }^{\circ} \mathrm{C}$ and the mortality was recorded after $24 \mathrm{~h}$ and $48 \mathrm{~h}$. The exposures were performed in at least three independent replicates with five earthworms per each exposure condition and replicate.

\section{Assessment of pesticides on enzymatic biomarkers Exposure to pesticide formulations}

Based on the data from the acute toxicity tests, for the following experiments sublethal concentrations were chosen. Since it was determined that the commercial preparations were more toxic than their active ingredient and only the commercial preparations are applied on fields, all subsequent exposures were performed with the commercial preparations only.

The following sublethal concentrations of the commercial preparations were chosen: Calypso 1.25, 2.5, 5 and $10 \mathrm{ng} / \mathrm{cm}^{2}$, Sumialfa $1.5625,3.125,6.25$ and $12.5 \mathrm{ng} / \mathrm{cm}^{2}$, Frontier $0.125,0.25,0.5$ and $1 \mu \mathrm{g} / \mathrm{cm}^{2}$ and Filon $0.25,0.5$, 1 and $2 \mu \mathrm{g} / \mathrm{cm}^{2}$. Concentrations of the commercial preparations are expressed as amounts of active substance 
in the formulation. Controls were also performed with distilled water only. Per each exposure condition 10 earthworms were exposed using the filter paper contact test as previously described. The whole experiment was repeated once to determine the repeatability of the results.

\section{Sample preparation}

After a 48-h exposure period each earthworm was weighed and then homogenized in cold sodium phosphate buffer $(0.1 \mathrm{M}, \mathrm{pH} 7.2$, in ratio $1: 5 \mathrm{w}: \mathrm{v})$ on ice with an Ultra-Turrax T18 homogenizer. Samples were then centrifuged $\left(30 \mathrm{~min}, 9000 \mathrm{~g}, 4^{\circ} \mathrm{C}\right.$ ). The supernatant (postmitochondrial fraction, S9) was transferred to a fresh tube and stored at $-80{ }^{\circ} \mathrm{C}$ until used for further enzymatic biomarker and oxidative stress measurements.

\section{Glutathione S-transferase (GST)}

Measurements of GST activity [20] were performed in 96-well plates with the reaction mixture consisting of $7.5 \mu \mathrm{L}$ sample (S9), $160 \mu \mathrm{L} 1-\mathrm{mM}$ CDNB (in sodium phosphate buffer) and $40 \mu \mathrm{L} 25-\mathrm{mM} \mathrm{GSH}$. Each sample was tested in triplicates. For the kinetics measurement of the reaction mixtures, absorbance was recorded using a Tecan Spark microplate reader at $340 \mathrm{~nm}$ for $2 \mathrm{~min}$ (measuring every $15 \mathrm{~s}$ ) at room temperature. After the amount of protein was determined for each sample, the specific enzyme activity was calculated and given in nmol of conjugated GSH in one min per mg of proteins.

\section{Catalase (CAT)}

The CAT activity measurements [6] were performed in cuvettes in duplicates, with the assay mixture containing $500 \mu \mathrm{L}$ sodium phosphate buffer $(0.1 \mathrm{M}, \mathrm{pH} 7.2), 500 \mu \mathrm{L}$ $\mathrm{H}_{2} \mathrm{O}_{2}(0.019 \mathrm{M})$ and $15 \mu \mathrm{L}$ of the sample (S9). For the kinetics measurements of the assay mixtures, absorbance was recorded using a Perkin-Elmer Lambda 25 UV-Vis spectrophotometer at $240 \mathrm{~nm}$ for 1 min (measuring every $15 \mathrm{~s})$ at $20{ }^{\circ} \mathrm{C}$. After the amount of protein was determined for each sample, the specific enzyme activity was calculated and given in $\mu \mathrm{mol}$ of degraded $\mathrm{H}_{2} \mathrm{O}_{2}$ in 1 min per mg of proteins.

\section{Glutathione reductase (GR)}

For the GR activity measurements [20] $10 \mu \mathrm{L}$ sample (S9), $100 \mu \mathrm{L}$ sodium phosphate buffer $(0.1 \mathrm{M}, \mathrm{pH} 7.2)$, $100 \mu \mathrm{L} 2 \mathrm{mM}$ GSSG and $10 \mu \mathrm{L} 1 \mathrm{mM}$ NADPH were added per well in 96-well plates. Each sample was tested in triplicates. For the kinetics measurement of the reaction mixtures, absorbance was recorded using a Tecan Spark microplate reader at $340 \mathrm{~nm}$ for $5 \mathrm{~min}$ (measuring every $20 \mathrm{~s}$ ) at $20{ }^{\circ} \mathrm{C}$. After the amount of protein was determined for each sample, the specific enzyme activity was calculated and given in nmol of reduced GSSG in 1 min per $\mathrm{mg}$ of proteins.

\section{Acetylcholine esterase (AChE)}

For the determination of AChE activity [12] $200 \mu \mathrm{L}$ sodium phosphate buffer (0.1 M, pH 7.2), $10 \mu \mathrm{L} 1.6 \mathrm{mM}$ DTNB, $20 \mu \mathrm{L} 156 \mathrm{mM}$ acetylthiocholine iodide and $7.5 \mu \mathrm{L}$ of the respective sample (S9) were added per well in 96-well plates and each sample tested in triplicates. For the kinetics measurement, absorbance was recorded using a Tecan Spark microplate reader at $412 \mathrm{~nm}$ for $2 \mathrm{~min}$ (measuring every $15 \mathrm{~s}$ ) at $20^{\circ} \mathrm{C}$. After the amount of protein was determined for each sample, the specific enzyme activity was calculated and given in nmol of acetylthiocholine iodide hydrolyzed in $1 \mathrm{~min}$ per mg of proteins.

\section{Carboxylesterase (CES)}

For the determination of CES activity [23] $10 \mu \mathrm{L}$ sample (S9) and $190 \mu \mathrm{L} 1 \mathrm{mM}$ 4-nitrophenyl acetate were added per well in 96-well plates in triplicate. For the kinetics measurement, absorbance was recorded using a Tecan Spark microplate reader at $405 \mathrm{~nm}$ for $2 \mathrm{~min}$ (measuring every $15 \mathrm{~s}$ ) at $20{ }^{\circ} \mathrm{C}$. After the amount of protein was determined for each sample, the specific enzyme activity was calculated and given in nmol of 4-nitrophenol produced per $1 \mathrm{~min}$ per $\mathrm{mg}$ of protein.

\section{Protein content determination}

The protein concentration in all samples was measured with Pierce ${ }^{\mathrm{TM}}$ BCA Protein Assay Kit (Thermo Fisher Scientific). Protein content was measured by adding $1.5 \mu \mathrm{L}$ of the sample to $23.5 \mu \mathrm{L}$ sodium phosphate buffer $(0.1 \mathrm{M}, \mathrm{pH} 7.2)$ and $200 \mu \mathrm{L}$ of the working solution (prepared according to the kit instructions) in 96-well plates. After a 2 -h incubation period at $20{ }^{\circ} \mathrm{C}$ absorbance was recorded using a Tecan Spark microplate reader at $562 \mathrm{~nm}$. Calibration curve was constructed with bovine serum albumin and protein concentrations calculated accordingly. The obtained protein concentrations were used for calculations of the specific enzyme activities.

\section{Assessment of pesticide effects on the oxidative stress level}

A fluorescence-based oxidative stress detection protocol was established based on the protocol previously 
developed for zebrafish larvae [26, 27]. For the detection of oxidative stress two fluorescence probes were used: CellTracker Green CMFDA for the detection of thiols and $\mathrm{CM}-\mathrm{H}_{2} \mathrm{DCFDA}$ for the detection of general reactive oxygen species. The samples were diluted in 1:10 ratio and added in triplicate to 96-well plates. For ROS detection $5 \mu \mathrm{L}$ sample, $95 \mu \mathrm{L}$ sodium phosphate buffer $(0.1 \mathrm{M}$, $\mathrm{pH}$ 7.2) and $5 \mu \mathrm{L} \mathrm{CM}-\mathrm{H}_{2}$ DCFDA $(7.87 \mu \mathrm{M})$ were added to the well, for GSH detection $1 \mu \mathrm{L}$ sample, $99 \mu \mathrm{L}$ sodium phosphate buffer $(0.1 \mathrm{M}, \mathrm{pH} 7.2)$ and $5 \mu \mathrm{L}$ CellTracker Green CMFDA $(9.78 \mu \mathrm{M})$ were added to the well. Blanks were performed in parallel. After an incubation period for $30 \mathrm{~min}$ at $25^{\circ} \mathrm{C}$, the fluorescence was measured using a Tecan Spark microplate reader at $485 \mathrm{~nm}$ (ex.) and $530 \mathrm{~nm}(\mathrm{em}$.) with the gain set to 50 . In order to confirm the proper functioning of the protocol, positive controls with GSH $(25 \mathrm{mM})$ and $\left.\mathrm{H}_{2} \mathrm{O}_{2} 0.019 \mathrm{M}\right)$ were performed (data not presented).

\section{Assessment of the impact of pesticides on multixenobiotic resistance (MXR) activity}

For investigation of effects of investigated pesticides on the MXR activity, the same concentrations were used as for the enzymatic biomarker and oxidative stress measurements, but separate exposures were performed. Determination of the MXR activity was performed using rhodamine $B(R B)$ retention protocol [21] in which pesticide stock solution and RB stock solution are mixed to get the final concentration of $100 \mu \mathrm{M} \mathrm{RB}$ and desired final concentration of pesticide. After evenly distributing $2 \mathrm{~mL}$ exposure solution per vial on the filter paper in the vials, one earthworm was placed in each vial and the vials were closed with a lid that provided a hole for ventilation. For the exposures controls of $100 \mu \mathrm{M} R \mathrm{R}$ were run in parallel. After a $48 \mathrm{~h}$ exposure in the dark at $20{ }^{\circ} \mathrm{C}$, sample preparation was conducted in the same manner as for measurement of enzyme activities and $10 \mu \mathrm{L}$ of each sample was added to $250 \mu \mathrm{L}$ phosphate buffer per well. The respective fluorescence was measured with a Tecan Spark microplate reader in triplicates in 96-well plates at $553 \mathrm{~nm}$ (ex.) and $578 \mathrm{~nm}$ (em.) with gain set to 55 . Calibration curve was constructed using RB (stock solutions were prepared in a 1:2 dilution row starting with $25 \mu \mathrm{M}$ $\mathrm{RB}$ ) and used for calculation of RB content in each. Then $10 \mu \mathrm{L}$ of the RB added to $250 \mu \mathrm{L}$ phosphate buffer per well. For expression of MXR activity, the protein concentration was taken into account and results were given in $\mathrm{nmol} \mathrm{RB}$ per mg proteins. The whole experiment was repeated to determine the repeatability of the results.

\section{Data analysis}

Data analyses of the acute toxicity data were performed using the statistical software R version 3.3.2 (R Core Team,
2016). Mortality calculations were based on the number of the observed dead earthworms after the 48-h exposure period. The logit procedure of the drc package within the $\mathrm{R}$ software environment was used for the determination of lethal concentrations $\left(\mathrm{LC}_{10}, \mathrm{LC}_{50}, \mathrm{LC}_{90}\right)$. Mortality concentration-response curves were fitted using a fourparameter logistic curve. The significant level of mean separation $(p<0.05)$ was based on a non-overlap between the $95 \%$ confidence limits of the $\mathrm{LC}_{50}$ values calculated after exposure to active substance vs. commercial formulation. The classification of pesticide toxicity was done according to Roberts and Dorough by taking into account $\mathrm{LC}_{50}$ values after 48 - $\mathrm{h}$ exposure to pesticides: supertoxic $\left(<1.0 \mu \mathrm{g} / \mathrm{cm}^{2}\right)$, extremely toxic $\left(1-10 \mu \mathrm{g} / \mathrm{cm}^{2}\right)$, very toxic $\left(10-100 \mu \mathrm{g} / \mathrm{cm}^{2}\right)$, moderately toxic $\left(100-1000 \mu \mathrm{g} / \mathrm{cm}^{2}\right)$, or relatively non-toxic $\left(>1000 \mu \mathrm{g} / \mathrm{cm}^{2}\right)$ [44].

Enzymatic biomarker data, fluorescence-based oxidative stress data and MXR activity data, were analyzed using GraphPad Prism 8 (GraphPad Software, Inc., California, USA). Prior to further analysis, data were checked for equality of variances (Bartlett test) and normality (Shapiro-Wilk test). Considering that the normal distribution of the data was obtained, one-way ANOVA was applied followed by the Dunnett's multiple comparison test to determine the significance levels reached in comparison to the control. The level of significance was set to $p<0.05$ throughout the study.

\section{Results \\ Lethal concentrations of investigated pesticides}

Lethal concentrations (LC) after exposure of earthworm $E$. andrei to the active insecticide ingredients thiacloprid and esfenvalerate and the active herbicide ingredients dimethenamid- $p$ and prosulfocarb, as well as the respective commercial preparations, are shown in Table 1. A comparison of the $\mathrm{LC}_{50}$ values for the active ingredients and commercial preparations shows that two out of four tested commercial preparations are significantly more toxic than their respective active ingredient alone. Based on the $48-\mathrm{h} \mathrm{LC}_{50}$ values, esfenvalerate and thiacloprid and their commercial preparations can be classified as super toxic, dimethenamid- $p$ and its commercial preparation as extremely toxic and prosulfocarb as very toxic while its commercial preparation can be classified as extremely toxic [44].

Significant differences between the $\mathrm{LC}_{50}$ values of the commercial preparation and respective active ingredient are marked with different letters.

\section{Responses of enzymatic biomarkers}

The specific enzyme activities measured in earthworms after exposure to different concentrations of the 
commercial pesticide preparation Calypso are presented in Fig. 1. Significant difference compared to control was observed only for CES activity at $2.5 \mathrm{ng} / \mathrm{cm}^{2}$.

Figure 2 shows the measured specific enzyme activities in earthworms exposed to the commercial pesticide preparation Sumialfa. The only significant difference in enzyme activity was observed for CAT after exposure to the highest concentration of $12.5 \mathrm{ng} / \mathrm{cm}^{2}$.

The results of the enzymatic biomarker measurements in E. andrei exposed to different concentrations of Filon are presented in Fig. 3. No significant changes were observed in any of the five measured enzymes.

Figure 4 shows the measured specific enzyme activities in earthworms exposed to different concentrations of the commercial pesticide preparation Frontier. A significant difference was observed only for CAT after exposure to the highest concentration of $1.0 \mu \mathrm{g} / \mathrm{cm}^{2}$.

\section{Fluorescence-based ROS and GSH determination}

Figures 5 and 6 show the relative fluorescence that was determined using two different fluorescent probes for the measurement of reactive oxygen species (ROS) and glutathione (GSH) after a 48-h exposure to the four different commercial pesticide preparations. For Calypso, significant changes could be detected for the measurement of ROS (Fig. 5) and GSH (Fig. 6). For the ROS detection, the three lowest concentrations showed a significant increase of relative fluorescence with the enzyme activity almost doubling, while only the lowest concentration showed a significant increase of relative fluorescence for the detection of GSH by a factor of approximately 1.5. For Frontier, a significant decrease by (more than) half in relative fluorescence could be observed for the detection of GSH after exposure to $0.125,0.25$ and $0.5 \mu \mathrm{g} / \mathrm{cm}^{2}$ (Fig. 6), but no significant differences to the control for the detection of ROS could be observed (Fig. 5). For both Sumialfa and Filon neither the detection of ROS nor the detection of GSH showed any significant differences of relative fluorescence.

\section{MXR activity}

Results of the relative rhodamine $B(R B)$ concentrations in earthworm E. andrei after exposures to four different commercial pesticide preparations are shown in Fig. 7. A significant increase in the relative RB concentration was detected for the insecticide Calypso at the highest concentration of $10 \mathrm{ng} / \mathrm{cm}^{2}$, while a significant decrease in relative RB content could be observed after exposure to the lowest concentration of $0.25 \mu \mathrm{g} /$ $\mathrm{cm}^{2}$ of the herbicide Filon. No significant changes in the relative $\mathrm{RB}$ concentration were detected following exposures to the insecticide Sumialfa and the herbicide Frontier. An increase in accumulated RB indicates an inhibition of the MXR activity, while a decrease of relative $\mathrm{RB}$ concentrations indicates an induction of the MXR activity.

Table 1 Lethal concentrations $\left(\mathrm{LC}_{10}, \mathrm{LC}_{50}\right.$ and $\left.\mathrm{LC}_{90}\right)$ and $95 \%$ confidence levels of the investigated pesticide active ingredients and their respective commercial preparations to earthworm $E$. andrei for $48 \mathrm{~h}$

\begin{tabular}{|c|c|c|c|c|c|c|c|}
\hline Active ingredient & Conc. $\left(\mu \mathrm{g} / \mathrm{cm}^{2}\right)$ & Lower limit & Upper limit & $\begin{array}{l}\text { Commercial } \\
\text { preparation }\end{array}$ & Conc. $\left(\mu \mathrm{g} / \mathrm{cm}^{2}\right)$ & Lower limit & Upper limit \\
\hline Thiacloprid & & & & Calypso & & & \\
\hline $\mathrm{LC}_{10}$ & 0.108 & -0.051 & 0.267 & $\mathrm{LC}_{10}$ & 0.013 & 0.010 & 0.017 \\
\hline $\mathrm{LC}_{50}$ & $0.510^{\mathrm{a}}$ & 0.774 & 1.794 & $\mathrm{LC}_{50}$ & $0.032^{b}$ & 0.027 & 0.036 \\
\hline $\mathrm{LC}_{90}$ & 2.407 & -8.917 & 13.730 & $\mathrm{LC}_{90}$ & 0.075 & 0.046 & 0.103 \\
\hline Esfenvalerate & & & & Sumialfa & & & \\
\hline $\mathrm{LC}_{10}$ & 0.017 & 0.011 & 0.023 & $\mathrm{LC}_{10}$ & 0.015 & -0.0003 & 0.031 \\
\hline $\mathrm{LC}_{50}$ & $0.032^{\mathrm{a}}$ & 0.026 & 0.040 & $\mathrm{LC}_{50}$ & $0.084^{\mathrm{a}}$ & 0.034 & 0.134 \\
\hline $\mathrm{LC}_{90}$ & 0.063 & 0.035 & 0.090 & $\mathrm{LC}_{90}$ & 0.462 & -0.234 & 1.159 \\
\hline Dimethenamid- $p$ & & & & Frontier & & & \\
\hline $\mathrm{LC}_{10}$ & 3.503 & 2.936 & 4.071 & $\mathrm{LC}_{10}$ & 1.387 & 0.863 & 1.912 \\
\hline$L C_{50}$ & $6.042^{\mathrm{a}}$ & 5.482 & 6.602 & $\mathrm{LC}_{50}$ & $2.524^{b}$ & 1.954 & 3.095 \\
\hline $\mathrm{LC}_{90}$ & 10.42 & 7.973 & 12.867 & $\mathrm{LC}_{90}$ & 4.593 & 1.867 & 7.319 \\
\hline Prosulfocarb & & & & Filon & & & \\
\hline $\mathrm{LC}_{10}$ & 5.138 & 2.197 & 8.073 & $L C_{10}$ & 2.373 & 0.592 & 4.154 \\
\hline $\mathrm{LC}_{50}$ & $12.464^{\mathrm{a}}$ & 7.257 & 17.671 & $\mathrm{LC}_{50}$ & $8.473^{a}$ & 4.475 & 12.470 \\
\hline $\mathrm{LC}_{90}$ & 30.256 & -3.313 & 63.826 & $\mathrm{LC}_{90}$ & 30.245 & -8.622 & 69.112 \\
\hline
\end{tabular}

$\mathrm{LC}_{50}$-values highlighted in italic letters 


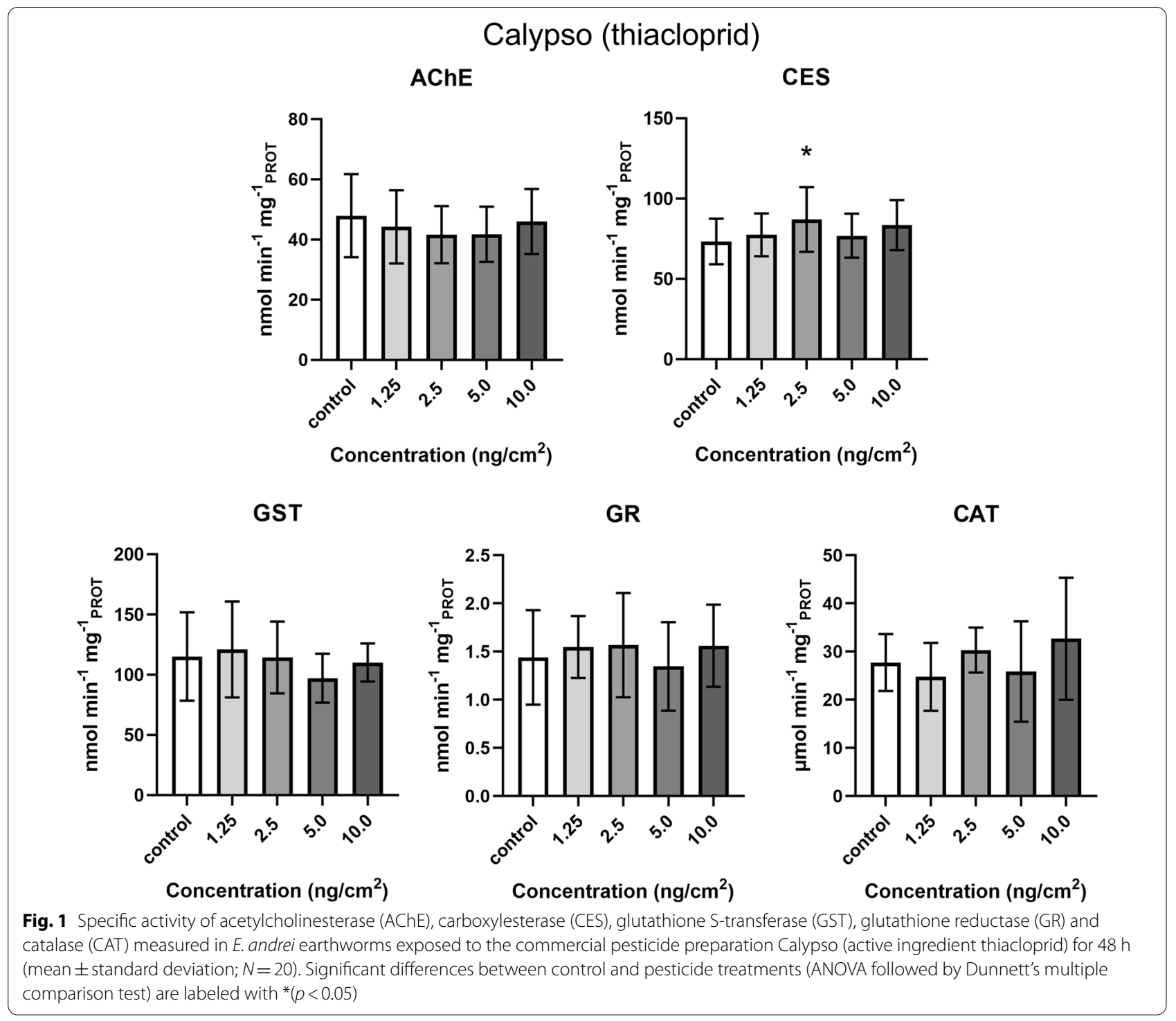

\section{Discussion}

The acute toxicity of four commonly used pesticides' active ingredients and their respective commercial preparations, as well as subcellular effects of the commercial preparations, on the earthworm E. andrei was investigated by applying the filter paper contact test. The investigated endpoints comprised assessment of acute toxicity, enzymatic activities, MXR activity and oxidative stress-related responses. The main mode of action of all four pesticides is well-known, with the herbicides dimethenamid- $p$ and prosulfocarb inhibiting long chain fatty acid synthesis [18], and the insecticides thiacloprid and esfenvalerate stimulating the nicotinic acetylcholine receptor and blocking sodium channels, respectively [32, 33, 46, 50]. Despite knowing the main toxicity mechanisms of the investigated pesticides, it is still not known in detail how they affect non-target organisms such as earthworms. Furthermore, while for example the mode of action of herbicides is mostly related to plant organisms, studies had shown that they often also adversely affect non-target animal organisms $[27,38,56]$.

\section{Acute toxicity}

The results of the filter paper contact tests showed that both insecticides could be classified as extremely toxic to the earthworm $E$. andrei, and the herbicides dimethenamid- $p$ and prosulfocarb could be classified extremely toxic and very toxic, respectively [44]. While there is no comparable data for the investigated herbicides on 


\section{Sumialfa (esfenvalerate)}

AChE

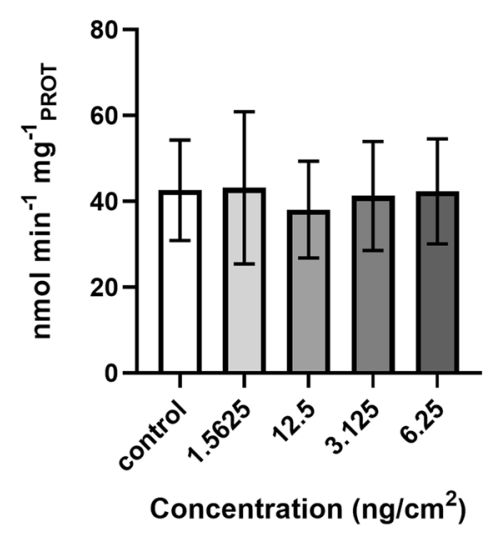

CES

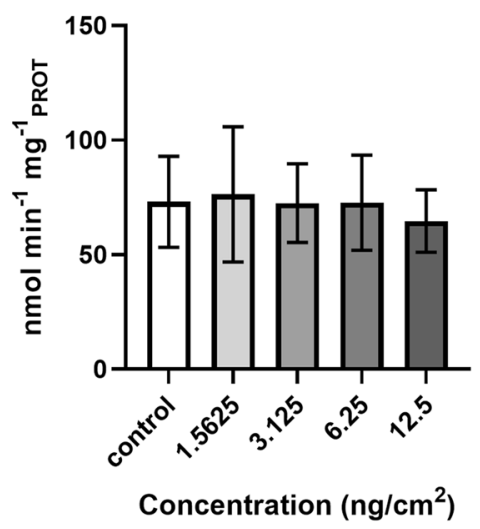

GR CAT

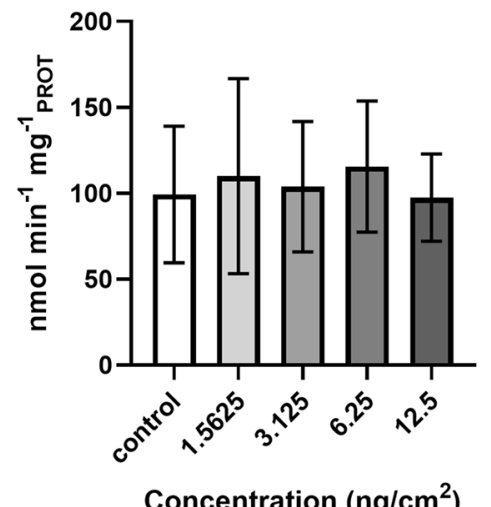

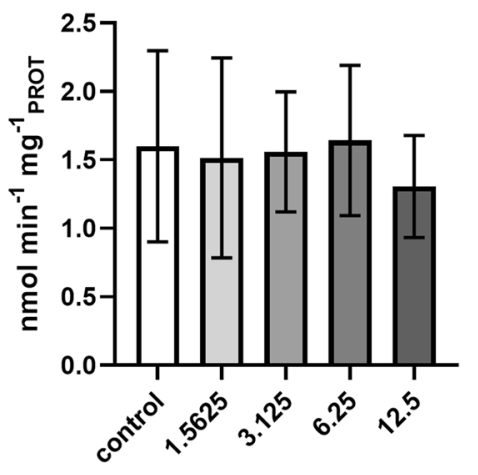

Concentration $\left(\mathrm{ng} / \mathrm{cm}^{2}\right)$

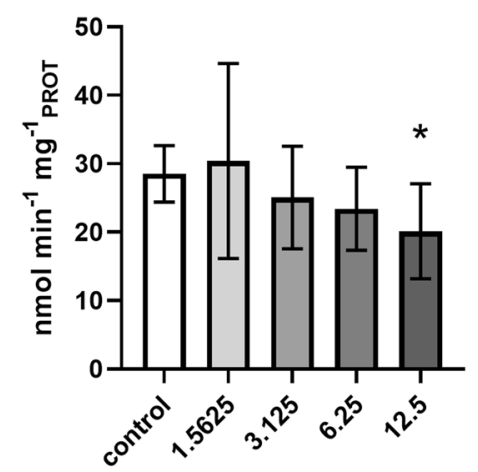

Concentration $\left(\mathrm{ng} / \mathrm{cm}^{2}\right)$

Fig. 2 Specific activity of acetylcholinesterase (AChE), carboxylesterase (CES), glutathione S-transferase (GST), glutathione reductase (GR) and catalase (CAT) measured in E. andrei earthworms exposed to the commercial pesticide preparation Sumialfa (active ingredient esfenvalerate) for $48 \mathrm{~h}$ (mean \pm standard deviation; $N=20$ ). Significant differences between control and pesticide treatments (ANOVA followed by Dunnett's multiple comparison test) are labeled with * $(p<0.05)$

earthworm toxicity available from literature, a study by Ye et al. investigated the comparative toxicity of fenvalerate and esfenvalerate. It showed similar toxicity results from the filter paper contact test for the earthworm Eisenia fetida with the $\mathrm{LC}_{50}$ of esfenvalerate after a $48 \mathrm{~h}$ exposure period being $0.68 \mu \mathrm{g} / \mathrm{cm}^{2}$ and therefore classified as super toxic [60]. A study by Wang et al. investigated the toxicity of 24 insecticides to E. fetida using the filter paper contact test including thiacloprid, which they classified as super toxic with an $\mathrm{LC}_{50}$ of $0.45 \mu \mathrm{g} / \mathrm{cm}^{2}$ [59].

Currently, all four pesticides are available on the European market, with dimethenamid- $p$ and prosulfocarb being sold in rather high tonnages and prosulfocarb being on the list of the most sold pesticides in Germany in 2019 [5]. While esfenvalerate is sold in rather small amounts in comparison, the main mode of action of insecticides often also affects a wide range of non-target organisms
$[3,11,45,54,56]$. The insecticide thiacloprid on the other hand has been on a substitution list since 2015 with the European Commission having recently decided against the re-approval due to its concerns about a potential for endocrine disruption [13].

Our results showed that the toxicity of the commercial preparations Calypso, Filon and Frontier can be higher than their respective active ingredient only. But only Calypso and Frontier gave significantly higher toxicity values. This, however, indicates that the current risk assessment might underestimate the actual toxicity of pesticides on the environment. The effects of solvents, dispersants and other adjuvant chemicals that are used to improve the durability, storage and application of the pesticides are not taken into account [7]. More and more studies have shown the discrepancy between the toxicity of active ingredients 


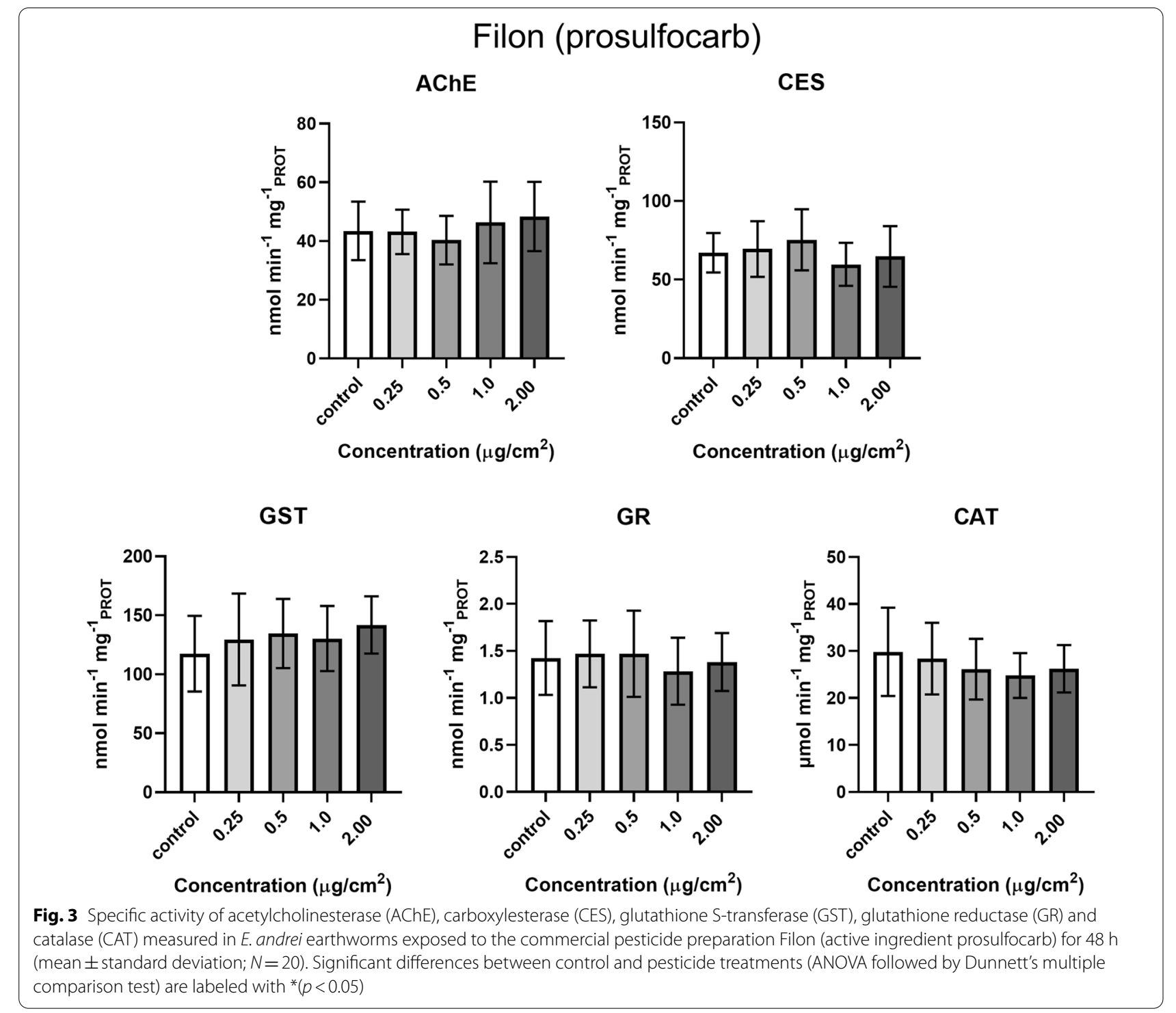

and commercial preparations with one of the most debated example being glyphosate and its commercial preparation Roundup [4, 24, 38]. A recent review by Nagy et al. on the toxicity of pesticide active ingredients and their product formulations showed that out of 36 studies, 24 studies reported a higher toxicity of the commercial formulation and only 8 showed a lower toxicity. Out of these 36 studies, a significant number of 10 studies focused on the comparative testing of glyphosate or glyphosate-based herbicides [34]. However, even though the effects of glyphosate and its preparation Roundup are subject of a highly controversial discussion, this problem also applies to most other pesticides that are not as intensely studied as glyphosate, making it more difficult to come to a consensus on how to improve risk assessment. Overall, there is very scarce information on the toxicity mechanisms available for the pesticides investigated in the present study and especially their commercial preparations $[9,29,43$, $45,58,60]$. This also supports Nagy et al. postulations of the inadequacy of current EU required assessments resulting in little information on the actual hazard from commercial pesticide formulations [34]. Therefore, the current study focused on assessing the toxicity mechanisms of the investigated commercial pesticide preparations.

\section{Oxidative stress}

In this study, a multiwell plate assay for the fluorescent detection of GSH and ROS, oxidative stress-related 


\section{Frontier (dimethenamid-p)}

AChE

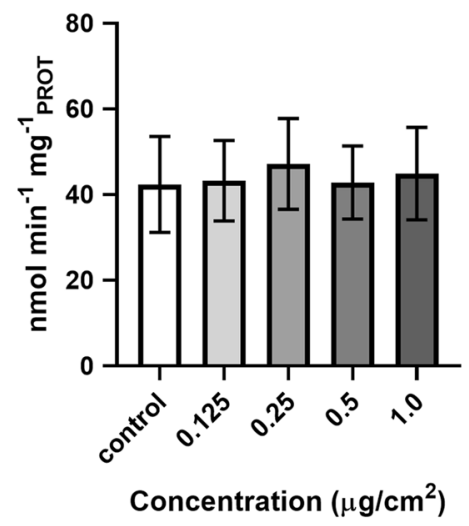

CES

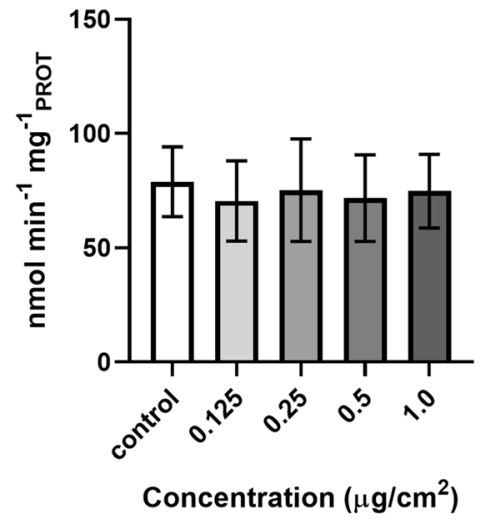

GST

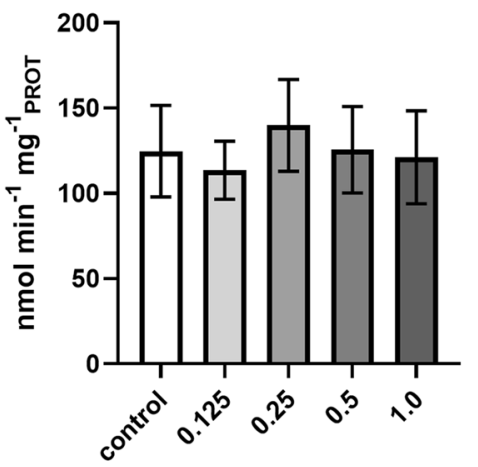

Concentration $\left(\mu \mathrm{g} / \mathrm{cm}^{2}\right)$

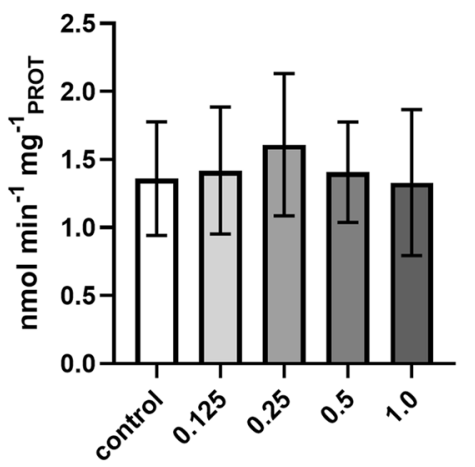

Concentration $\left(\mu \mathrm{g} / \mathrm{cm}^{2}\right)$

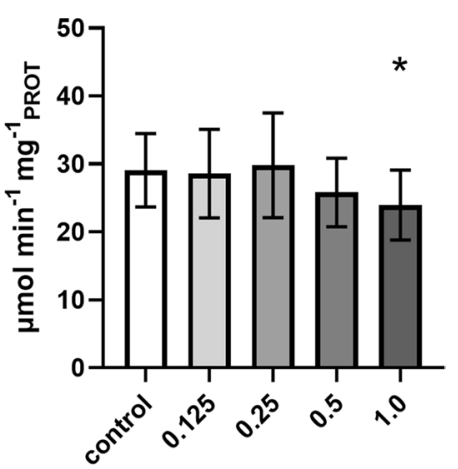

Concentration $\left(\mu \mathrm{g} / \mathrm{cm}^{2}\right)$

Fig. 4 Specific activity of acetylcholinesterase (AChE), carboxylesterase (CES), glutathione S-transferase (GST), glutathione reductase (GR) and catalase (CAT) measured in $E$. andrei earthworms exposed to the commercial pesticide preparation Frontier (active ingredient dimethenamid-p) for $48 \mathrm{~h}$ (mean \pm standard deviation; $N=20$ ). Significant differences between control and pesticide treatments (ANOVA followed by Dunnett's multiple comparison test) are labeled with * $(p<0.05)$

responses, in the earthworm S9-fraction was established based on a previous protocol for the detection in zebrafish larvae [26, 27]. Oxidative stress occurs due to an imbalance of the natural ROS molecules and antioxidants, e.g., GSH-the primary redox buffer [35]. It has been shown in various studies that oxidative stress is often related to the toxicity of pesticides [30, 31, 54, 56, 57]. In this study, the pesticides Calypso (thiacloprid) and Frontier (dimethenamid- $p$ ) showed effects on the ROS and GSH levels (Figs. 5 and 6). Specifically, Calypso showed an increase by over $100 \%$ in relative fluorescence, indicating a high increase in ROS levels after exposures to Calypso. The assessment of GSH levels showed an increase only in the lowest concentration of Calypso. An increase in GSH levels shows a response of the antioxidant system and the induction of oxidative stress. The herbicide Frontier also affected GSH levels in exposed earthworm, however, in this case the opposite effect was observed with a decrease in GSH levels after exposures to the three lowest concentrations. While no significant differences in ROS levels could be detected, this might be due to the antioxidant system still being able to make up for any increased production of ROS. A similar fluorescence-based method to assess ROS levels in earthworm E. fetida has been used by Wang et al. after exposures to the neonicotinoid insecticide imidacloprid [57], where a significant increase of ROS levels could be shown after long-term exposures in soil. Another study by Liu et al., which also assessed long-term oxidative stress-related responses of $E$. fetida after neonicotinoid exposure by means of fluorescent ROS detection showed an increase of ROS levels for different exposure times such as 7 days and 28 days [30]. However, there seems to be very little understanding yet of short exposure effects 

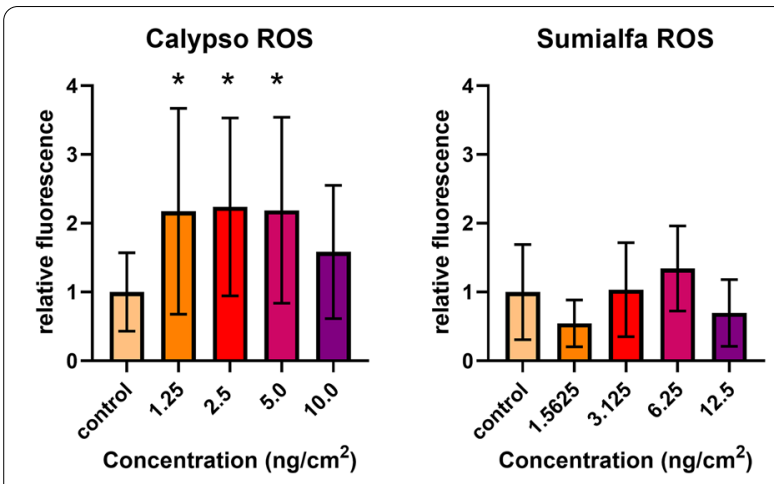

Filon ROS
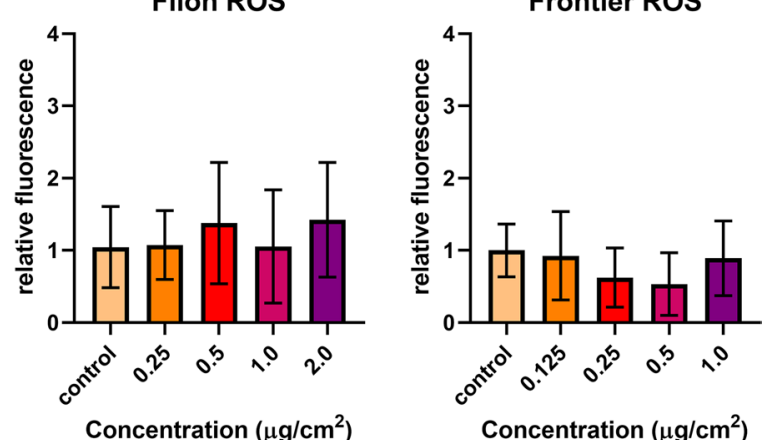

Fig. 5 Relative fluorescence for reactive oxygen species (ROS) measurements in Eisenia andrei exposed to the four commercial pesticide preparations Calypso (active ingredient thiacloprid), Sumialfa (active ingredient fenvalerate), Filon (active ingredient prosulfocarb) and Frontier (active ingredient dimethenamid- $p$ ) for $48 \mathrm{~h}$ (mean \pm standard deviation; $N=20$ ). Significant differences between control and pesticide treatments (ANOVA followed by Dunnett's multiple comparison test) are labeled with $*(p<0.05)$ in earthworms on ROS or GSH levels after exposures to pesticides and especially herbicides. Therefore, the protocol for oxidative stress detection established here can be a helpful and sensitive, yet simple and easy tool to investigate both ROS and GSH levels to gain a better understanding of non-enzymatic oxidative stress-related responses.

\section{Enzymatic biomarker responses}

When comparing the results of the fluorescence probebased assay for oxidative stress detection with enzymatic biomarkers, the fluorescence-based assay proved to be more sensitive for observing oxidative stress responses after short exposure at low concentrations, as for Calypso (thiacloprid) no significant change in responses of enzymatic biomarkers for oxidative stress, such as GST (also a phase II detoxification enzyme) or CAT, was observed (Fig. 1). However, CAT activity was decreased after

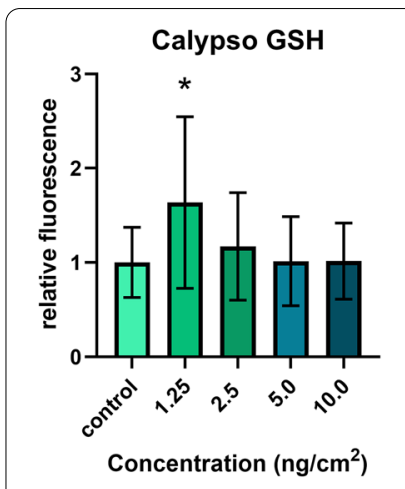

Filon GSH

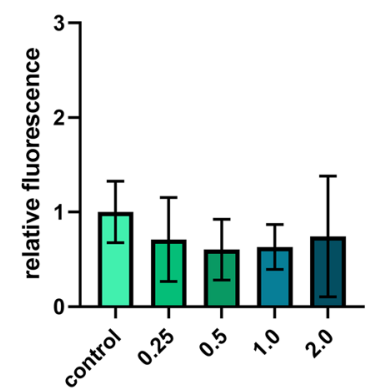

Concentration $\left(\mu \mathrm{g} / \mathrm{cm}^{2}\right)$

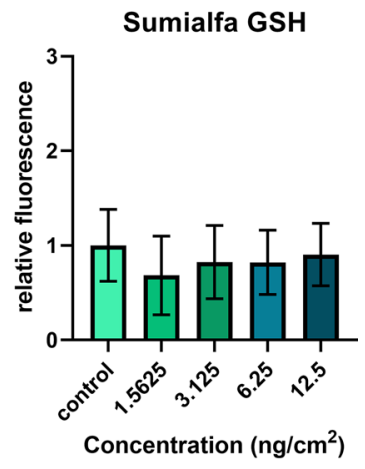

Frontier GSH

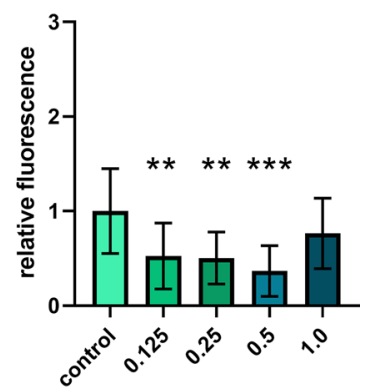

Concentration $\left(\mu \mathrm{g} / \mathrm{cm}^{2}\right)$
Fig. 6 Relative fluorescence for glutathione (GSH) measurements in Eisenia andrei exposed to four commercial pesticide preparations Calypso (active ingredient thiacloprid), Sumialfa (active ingredient esfenvalerate), Filon (active ingredient prosulfocarb) and Frontier (active ingredient dimethenamid-p) for $48 \mathrm{~h}$ (mean \pm standard deviation; $N=20$ ). Significant differences between control and pesticide treatments (ANOVA followed by Dunnett's multiple comparison test) are labeled with ${ }^{*}(p<0.05),{ }^{* *}(p<0.01)$ and $* * *(p<0.001)$ exposure to the highest concentration of both Sumialfa (esfenvalerate) and Frontier (dimethenamid- $p$ ) (Figs. 2 and 3), suggesting that the enzymatic responses may respond slower, with possibly different results for longer exposure periods. These results are supported by our previous study where the effects of the pesticides diuron and diazinon were investigated using the fluorescent probes, as well as the enzymatic biomarkers and also showed that the fluorescent probes-based assessment of oxidative stress might be more sensitive or that the enzymatic antioxidant reactions are slower compared to the GSH reaction $[54,56]$. There are no other studies assessing oxidative stress induction of pesticides investigated herein, thus making comparisons difficult. However, there have been several studies elucidating oxidative stress to be a common mode of action of pesticide toxicity even though the responses might not always be univocal. A review by Lukaszewicz-Hussein looks at oxidative stress induced by the group of organophosphate pesticide exposure whose 

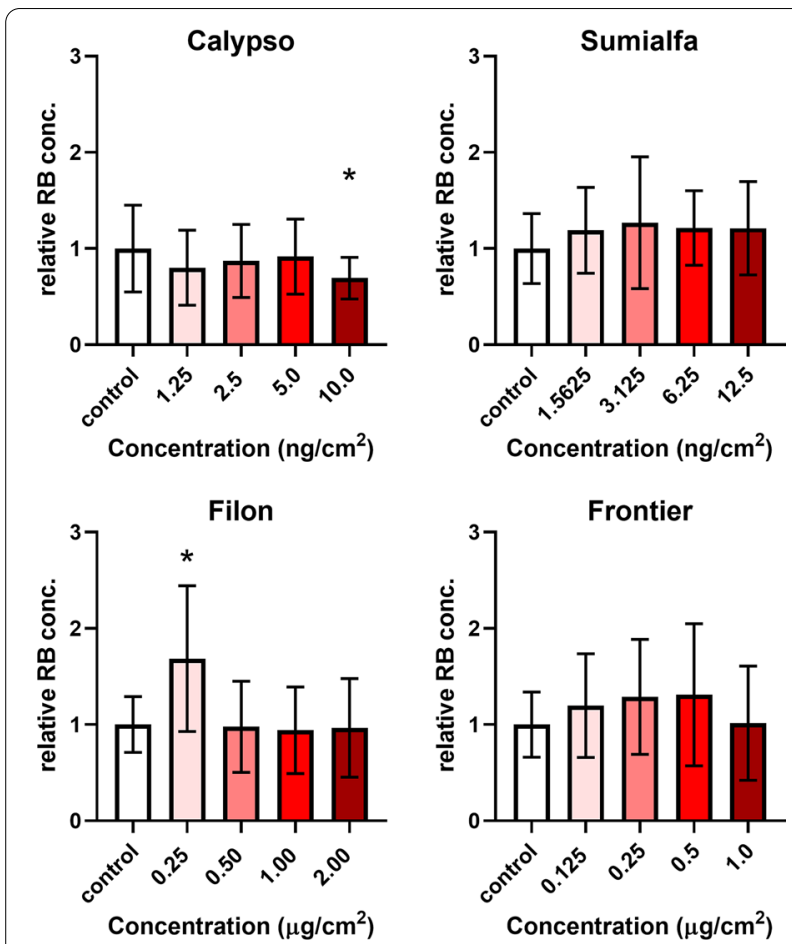

Fig. 7 Relative rhodamine $B(R B)$ concentration for the measurement of MXR activity in Eisenia andrei exposed for $48 \mathrm{~h}$ to the commercial pesticide preparations Calypso (active ingredient thiacloprid), Sumialfa (active ingredient esfenvalerate), Filon (active ingredient prosulfocarb) and Frontier (active ingredient dimethenamid- $p$ ) (mean \pm standard deviation; $N=20$ ). Significant differences between control and pesticide treatments (ANOVA followed by Dunnett's multiple comparison test) are labeled with * $(p<0.05)$

main mode of action is the inhibition of AChE, showing that oxidative stress is another mode of action through which they cause adverse effects [31]. Furthermore, there are also various studies looking at the effects of oxidative stress-related enzyme responses in earthworm, mostly $E$. fetida, showing the effects on not only CAT or GST but also peroxidase, superoxide dismutase or malonaldehyde $[30,48,52,53,57,62]$.

While this shows, that oxidative stress often occurs as a result of pesticide exposure and often contributes to pesticide toxicity, other biomarkers can also be used to elucidate more specific toxicity mechanisms and modes of action. Other enzymatic biomarkers that were assessed besides the biomarkers for oxidative stress were AChE activity and CES activity. Acetylcholinesterase is an important enzyme in neuronal transmission, while carboxylesterase is a phase I detoxification enzyme [35]. AChE activity was not affected by any of the pesticide exposures, suggesting that an inhibition of AChE is not the mechanism of action of the investigated pesticides and rather oxidative stress. On the other hand, an increase in CES activity could be observed after exposure to Calypso. As Calypso also affected the MXR activity, overall Calypso seems to affect various forms of detoxification mechanisms. A study by Feng et al. had investigated the long-term effects of the active ingredient thiacloprid in soil and could also show a significant decrease in CES activity after a 7-day exposure period [15].

\section{MXR activity}

In the assessment of multixenobiotic resistance activity, an important first line of defense to toxic compounds, earthworm exposed to the pesticides Calypso (thiacloprid) and Filon (prosulfocarb) significantly affected accumulation of rhodamine B (Fig. 7). The RB concentration in earthworms exposed to the highest concentration of Calypso decreased significantly, indicating an induction of the MXR activity. The induction of MXR suggests that as a first line of defense, the activity is increased to evict the toxic substance out of the cells. An opposite effect was observed after the exposure to the lowest concentration of Filon, with an increase in RB content, which represents an inhibition of the MXR activity. This indicates, that the efflux pumps are unable to expel the toxins, therefore increasing the exposure time of the pesticide within the cell and increasing the time to exert toxic effects $[54,56]$. Regarding the no observed effect at higher Filon concentrations, it is possible that at lower concentrations the pesticide causes an inhibition of MXR activity, whereas at the higher concentrations cells activate defense mechanisms and prevent inhibition of MXR activity in order to alleviate toxic effects. No previous research assessed effects of the investigated pesticides on the MXR activity on earthworm or other species. However, multiple studies assessed the effects of other pesticides on MXR activity in earthworms and both inhibition and induction of MXR activity was observed. Velki et al. observed an inhibition of MXR activity after individual exposures to four commercial pesticide preparations, namely MaximExtra 050 (difenoconazole + fludioxonil), Koban $\mathrm{T}$ (pethoxamid +terbuthylazine), Pyrus 400 SC (pyrimethanil), and Cruiser 350 FS (thiamethoxam) [56]. Similar to the inhibition of MXR activity by the herbicide Filon (prosulfocarb), in a previous study, we observed the inhibition of MXR activity after the exposure of $E$. andrei to two herbicides [27]. Other studies also showed an inhibition of MXR activity caused by insecticides such as deltamethrin or a time-dependent induction and then inhibition after exposure to dimethoate [21, 52, 53]. This emphasizes the various impacts pesticides can have on the defense system of earthworm cells, thus increasing the potential adverse effects they can have on this important soil organism and the soil ecosystem. 


\section{Conclusions}

Present study showed that commercial preparations can be more toxic compared to their respective active ingredients and that effects of the investigated pesticide formulations can be observed on a subcellular level already after $48 \mathrm{~h}$ exposure. Furthermore, a fluorescence-based method for ROS and GSH was established, providing a sensitive tool for the detection of oxidative stress-related responses. Overall, the insecticide Calypso (thiacloprid) showed the most diverse effects, as it affected CES activity, ROS and GSH levels as well as MXR activity. Both the insecticide Sumialfa (esfenvalerate) and the herbicide Frontier (dimethenamid- $p$ ) caused a decrease in CAT activity, while Frontier also decreased GSH levels. Filon (prosulfocarb) did not show any effects on enzymatic biomarkers but caused an inhibition of MXR activity. Considering the obtained results, there is a need to involve commercial preparations of pesticides into the risk assessment of pesticides. Toxicity classifications of the investigated pesticides indicate that they can have adverse effects on key species of soil ecosystems at low concentrations. The exposure of $48 \mathrm{~h}$ might have been too short to observe more effects on enzymatic biomarkers, however, first indications were obtained for various effects on cellular defense mechanisms also using fluorescence-based assays for the determination of oxidative stress and MXR activity. Future studies should assess effects of these pesticides in soil as well to include influences of the soil matrix on availability and toxicity. Furthermore, assessments on higher levels of biological organization are needed in order to determine the potential risks to the soil ecosystem.

\section{Abbreviations}

CAT: Catalase; CES: Carboxylesterase; GSH: Glutathione; GR: Glutathione reductase; GST: Glutathione S-transferase; MXR: Multixenobiotic resistance; RB: Rhodamine B; ROS: Reactive oxygen species.

\section{Acknowledgements}

The authors kindly thank the Deutsche Bundesstiftung Umwelt (DBU, German Federal Environmental Foundation) for a personal scholarship granted to Carina Lackmann.

The Tecan Spark microplate reader was purchased with the Alexander von Humboldt Foundation equipment grant awarded to Dr. Mirna Velki.

\section{Authors' contributions}

Conceptualization: CL, MV, TBS and HH. Investigations: CL, DB and SE. Data analysis: $C L$ and MV. Writing: $C L$ and MV. Review and editing: all. All authors read and approved the final manuscript.

\section{Funding}

Open Access funding enabled and organized by Projekt DEAL. The authors kindly thank the Deutsche Bundesstiftung Umwelt (DBU, German Federal Environmental Foundation) for a personal scholarship granted to Carina Lackmann and Alexander von Humboldt Foundation for an equipment grant awarded to Dr. Mirna Velki.

\section{Availability of data and materials}

The datasets used and/or analyzed during the current study are available from the corresponding author on reasonable request.
Ethics approval and consent to participate Not applicable.

\section{Consent for publication}

Not applicable.

\section{Competing interests}

The authors declare that they have no competing interests.

\section{Author details}

${ }^{1}$ Department of Evolutionary Ecology and Environmental Toxicology, Goethe University Frankfurt, Max-von-Laue-Str. 13, 60438 Frankfurt am Main, Germany. ${ }^{2}$ Department of Ecosystem Analysis, Institute for Environmental Research, RWTH Aachen University, Worringerweg 1, 52074 Aachen, Germany. ${ }^{3}$ Department of Biology, Josip Juraj Strossmayer University of Osijek, Cara Hadrijana 8/A, 31000 Osijek, Croatia. ${ }^{4}$ Ruhr District Institute of Hygiene, Rotthauser Str. 21, 45879 Gelsenkirchen, Germany. ${ }^{5}$ LOEWE Centre for Translational Biodiversity Genomics (LOEWE-TBG), 60325 Frankfurt am Main, Germany.

Received: 1 November 2020 Accepted: 21 January 2021

Published online: 02 February 2021

\section{References}

1. Blouin M, Hodson ME, Delgado EA, Baker G, Brussaard L, Butt KR, Dai J, Dendooven L, Peres G, Tondoh JE, Cluzeau D, Brun J-J (2013) A review of earthworm impact on soil function and ecosystem services. Eur J Soil Sci 64:161-182. https://doi.org/10.1111/ejss.12025

2. Bošnjak I, Bielen A, Babić S, Šver L, Popović NT, Čož-Rakovac R, Klobučar RS (2014) First evidence of the P-glycoprotein gene expression and multixenobiotic resistance modulation in earthworm. Arch Ind Hyg Toxicol 65:67-75. https://doi.org/10.2478/10004-1254-65-2014-2421

3. Brander SM, Mosser CM, Geist J, Hladik ML, Werner I (2012) Esfenvalerate toxicity to the cladoceran Ceriodaphnia dubia in the presence of green algae, Pseudokirchneriella subcapitata. Ecotoxicology 21:2409-2418. https ://doi.org/10.1007/s10646-012-0996-y

4. Bridi D, Altenhofen S, Gonzalez JB, Reolon GK, Bonan CD (2017) Glyphosate and Roundup ${ }^{\circledR}$ alter morphology and behavior in zebrafish. Toxicology 392:32-39. https://doi.org/10.1016/j.tox.2017.10.007

5. BVL (2020) Absatz an Pflanzenschutzmitteln in der Bundesrepublik Deutschland, pp 1-20

6. Claiborne Al (1985) Catalase activity. In: Handbook of methods in oxygen radical research, pp 283-284

7. Damalas CA, Eleftherohorinos IG (2011) Pesticide exposure, safety issues, and risk assessment indicators. Int J Environ Res Public Health. https://doi. org/10.3390/ijerph8051402

8. Datta S, Singh J, Singh S, Singh J (2016) Earthworms, pesticides and sustainable agriculture: a review. Environ Sci Pollut Res 23:8227-8243. https //doi.org/10.1007/s11356-016-6375-0

9. Devault DA, Guillemin J, Millet M, Eymery F, Hulin M, Merlo M (2019) Prosulfocarb at center stage! Environ Sci Pollut Res. https://doi.org/10.1007/ s11356-019-06928-8

10. EASAC (2015) Ecosystem services, agriculture and neonictinoids (Issue April).

11. Elden JBB, Lydy MJ (2006) Joint toxicity of chlorpyrifos and esfenvalerate to fathead minnows and midge larvae. Environ Toxicol Chem 25(2):623629. https://doi.org/10.1897/05-370R.1

12. Ellman GL, Courtney KD, Andres VJ, Featherstone RM (1961) A new and rapid colorimetric determination of acetylcholinesterase activity. Biochem Pharmacol 7:88-95. https://doi.org/10.1016/0006-2952(61)90145-9

13. European Commission (2020) Durchführungsverordnung(EU) 2020/23 der Kommission vom 13. Januar 2020 zur Nichterneuerung der Genehmigung für den Wirkstoff Thiacloprid gemäß der Verordnung (EG) Nr. 1107/2009 des Europäischen Parlaments und des Rates über das Inverkehrbringen von Pflan, Issue 540, pp 2009-2012. https://doi. org/10.2903/j.efsa.2019.5595

14. Eyhorn F, Muller A, Reganold JP, Frison E, Herren HR, Luttikholt L, Mueller A, Sanders J, Scialabba NE, Seufert V, Smith P (2019) Sustainability in global agriculture driven by organic farming. Nat Sustain 2:253-255. https ://doi.org/10.1038/s41893-019-0266-6 
15. Feng $L$, Zhang $L$, Zhang $Y$, Zhang $P$, Jiang $H$ (2015) Inhibition and recovery of biomarkers of earthworm Eisenia fetida after exposure to thiacloprid. Environ Sci Pollut Res 22:9475-9482. https://doi.org/10.1007/s1135 6-015-4122-6

16. Food and Agriculture Organization of the United Nations (2020) Pesticides use. http://www.fao.org/faostat/en/?\#data/RP/visualize

17. Fründ HC, Graefe U, Tischer S (2010) Earthworms as Bioindicators of Soil Quality. Biology of Earthworms. Springer, Berlin. https://doi. org/10.1007/978-3-642-14636-7_16

18. Fuerst EP (1987) Understanding the mode of action of the chloroacetamide and thiocarbamate herbicides, vol 1, Issue 4. Cambridge University Press on behalf of the Weed Science Society of America, pp 270-277. http://www.jstor.org/stable/3987000

19. Geiger F, Bengtsson J, Berendse F, Weisser WW, Emmerson M, Morales MB, Ceryngier P, Liira J, Tscharntke T, Winqvist C, Eggers S, Bommarco R, Pärt T, Bretagnolle V, Plantegenest M, Clement LW, Dennis C, Palmer C, Onate $J$ J et al (2010) Persistent negative effects of pesticides on biodiversity and biological control potential on European farmland. Basic Appl Ecol 11:97-105. https://doi.org/10.1016/j.baae.2009.12.001

20. Habig WH, Jakoby WB (1981) Assays for differentiation of glutathione S-transferases. Methods Enzymol 77:398-405. https://doi.org/10.1016/ S0076-6879(81)77053-8

21. Hackenberger BK, Velki M, Stepic S, Hackenberger DK (2012) First evidence for the presence of efflux pump in the earthworm Eisenia andrei. Ecotoxicol Environ Saf 75:40-45. https://doi.org/10.1016/j.ecoen v.2011.06.024

22. Hasenbein S, Peralta J, Lawler SP, Connon RE (2017) Environmentally relevant concentrations of herbicides impact non-target species at multiple sublethal endpoints. Sci Total Environ 607-608:733-743. https:// doi.org/10.1016/j.scitotenv.2017.06.270

23. Hosokawa M, Satoh T (2001) Measurement of carboxylesterase (CES). Curr Protoc Toxicol 10:4.7.1-4.7.14. https://doi.org/10.1002/0471140856.tx040 $7 \mathrm{~s} 10$

24. Janssens L, Stoks R (2017) Stronger effects of Roundup than its active ingredient glyphosate in damsel fly larvae. Aquat Toxicol 193:210-216. https://doi.org/10.1016/j.aquatox.2017.10.028

25. Kiyasudeen K, Ibrahim MH, Quaik S, Ismail SA (2016) Vermicomposting : an earthworm mediated waste treatment technique. Prospects of organic waste management and the significance of earthworms Applied environmental science and engineering for a sustainable future. Springer, Cham, pp 167-199. https://doi.org/10.1007/978-3-319-24708-3

26. Lackmann C, Santos M, Rainieri S, Barranco A, Hollert H, Spirhanzlova P, Velki M, Seiler T-B (2018) Novel procedures for whole organism detection and quantification of fluorescence as a measurement for oxidative stress in zebrafish (Danio rerio) larvae. Chemosphere 197:200-209. https://doi. org/10.1016/j.chemosphere.2018.01.045

27. Lackmann C, Velki M, Seiler TB, Hollert H (2018) Herbicides diuron and fluazifop-p-butyl affect avoidance response and multixenobiotic resistance activity in earthworm Eisenia andrei. Chemosphere 210:1 10-119. https://doi.org/10.1016/j.chemosphere.2018.07.008

28. Landrigan PJ, Fuller R, Acosta NJR, Adeyi O, Arnold R, Basu N, Baldé AB, Bertollini R, Bose-O'Reilly S, Boufford JI, Breysse PN, Chiles T, Mahidol C, Coll-Seck AM, Cropper ML, Fobil J, Fuster V, Greenstone M, Haines A et al (2018) The Lancet Commission on pollution and health. Lancet 391(10119):462-512. https://doi.org/10.1016/S0140-6736(17)32345-0

29. Lima Silva C, De Brennan N, Brouwer JM, Commandeur D, Verweij RA, van Gestel CAM (2017) Comparative toxicity of imidacloprid and thiacloprid to different species of soil invertebrates. Ecotoxicology 26:555-564. https ://doi.org/10.1007/s10646-017-1790-7

30. Liu T, Wang X, You X, Chen D, Li Y, Wang F (2017) Oxidative stress and gene expression of earthworm (Eisenia fetida) to clothianidin. Ecotoxicol Environ Saf 142:489-496. https://doi.org/10.1016/j.ecoenv.2017.04.012

31. Lukaszewicz-Hussain A (2010) Role of oxidative stress in organophosphate insecticide toxicity - short review. Pestic Biochem Physiol 98:145-150. https://doi.org/10.1016/j.pestbp.2010.07.006

32. Matsuda K, Kanaoka S, Akamatsu M, Sattelle DB (2009) Diverse actions and target-site selectivity of neonicotinoids: structural insights. Mol Pharmacol 76(1):1-10. https://doi.org/10.1124/mol.109.055186.The

33. Matsuda K, Shimomura M, Ihara M, Akamatsu M, Sattelle DB (2005) Neonicotinoids show selective and diverse actions on their nicotinic receptor targets: electrophysiology, molecular biology, and receptor modeling studies. Biosci Biotechnol Biochem ISSN 69(8):1347-6947. https://doi. org/10.1271/bbb.69.1442

34. Nagy K, Duca RC, Lovas S, Creta M, Scheepers PTJ, Godderis L, Ádám B (2020) Systematic review of comparative studies assessing the toxicity of pesticide active ingredients and their product formulations. Environ Res 181:108926. https://doi.org/10.1016/j.envres.2019.108926

35. Nikinmaa M (2014) An introduction to aquatic toxicology. Academic Press, New York. https://doi.org/10.1016/C2012-0-07948-3

36. OECD (1984) OECD Guideline 207: earthworm, acute toxicity tests. OECD Publishing, Paris

37. Paoletti MG (1999) The role of earthworms for assessment of sustainability and as bioindicators. Agric Ecosyst Environ 74:137-155. https://doi. org/10.1016/S0167-8809(99)00034-1

38. Pereira JL, Antunes SC, Castro BB, Marques CR, Gonc AMM, Pereira R (2009) Toxicity evaluation of three pesticides on non-target aquatic and soil organisms: commercial formulation versus active ingredient. Ecotoxicology 18:455-463. https://doi.org/10.1007/s10646-009-0300-y

39. Pérès $G$, Vandenbulcke $F$, Guernion $M$, Hedde $M$, Beguiristain T, Douay F, Houot S, Piron D, Richard A, Bispo A, Grand C, Galsomies L, Cluzeau D (2011) Earthworm indicators as tools for soil monitoring, characterization and risk assessment. An example from the national Bioindicator programme (France). Pedobiol Int J Soil Biol 54:S77-S87. https://doi. org/10.1016/j.pedobi.2011.09.015

40. Persson LM, Breitholtz M, Cousins IT, De Wit CA, MacLeod M, McLachlan S (2013) Confronting unknown planetary boundary threats from chemical pollution. Environ Sci Technol 47:12619-12622. https://doi.org/10.1021/ es402501c

41. Ramirez T, Strigun A, Verlohner A, Huener H-A, Peter E, Herold M, Bordag N, Mellert W, Walk T, Spitzer M, Jiang X, Sperber S, Hofmann T, Hartung T, Kamp H, Ravenzwaay BV (2018) Prediction of liver toxicity and mode of action using metabolomics in vitro in HepG2 cells. Arch Toxicol 92(2):893-906. https://doi.org/10.1007/s00204-017-2079-6

42. Reganold JP, Wachter JM (2016) Organic agriculture in the twenty-first century. Nature Publishing Group 2:1-8. https://doi.org/10.1038/nplan ts. 2015.221

43. Renaud M, Akeju T, Natal-da-luz T, Leston S, Ramos F, Sousa JP, AzevedoPereira HM (2018) Effects of the neonicotinoids acetamiprid and thiacloprid in their commercial formulations on soil fauna. Chemosphere 194:85-93. https://doi.org/10.1016/j.chemosphere.2017.11.102

44. Roberts BL, Dorough HW (1984) Relative toxicities of chemicals to the earthworm Eisenia foetida. Environ Toxicol Chem 3:67-78. https://doi. org/10.1002/etc.5620030109

45. Rosa R, Bordalo MD, Soares AMVM, Pestana JLT (2016) Effects of the pyrethroid esfenvalerate on the oligochaete, Lumbriculus variegatus. Bull Environ Contam Toxicol 96(4):438-442. https://doi.org/10.1007/s0012 8-015-1718-y

46. Sattelle DB, Yamamoto D (1985) Molecular targets of pyrethroid insecticides. In: Evans PD, Wigglesworth VB (eds) Advances in insect physiology, vol 20. Academic Press, New York, pp 147-213

47. Schäffer A, Filser J, Frische T, Gessner M, KöckW, Kratz W, Liess M, RoßNickoll M, Schäfer R, Scheringer M (2018) The silent spring —on the need for sustainable plant protection (Issue 16). German National Academy of Sciences Leopoldina.

48. Schreck E, Geret F, Gontier L, Treilhou M (2008) Neurotoxic effect and metabolic responses induced by a mixture of six pesticides on the earthworm Aporrectodea caliginosa nocturna. Chemos 71:1832-1839. https:// doi.org/10.1016/j.chemosphere.2008.02.003

49. Sharma A, Kumar V, Shahzad B, Tanveer M, Sidhu GPS, Handa N, Kohli SK, Yadav P, Bali AS, Parihar RD, Dar OI, Singh K, Jasrotia S, Bakshi P, Ramakrishnan M, Kumar S, Bhardwaj R, Thukral AK (2019) Worldwide pesticide usage and its impacts on ecosystem. SN Appl Sci 1(11):1-16. https://doi. org/10.1007/s42452-019-1485-1

50. Soderlund DM, Bloomquist R (1989) Neurotoxic actions of pyrethroid insecticides. Annu Rev Entomol 34:77-96. https://doi.org/10.1146/annur ev.en.34.010189.000453

51. Steffen W, Richardson K, Rockström J, Cornell SE, Fetzer I, Bennett EM, Biggs R, Carpenter SR, Vries WD, De Wit CA, Folke C, Gerten D, Heinke J, Mace GM, Persson LM, Ramanathan V, Reyers B, Sörlin S (2015) Planetary boundaries : guiding changing planet. Science 347:1259855. https://doi. org/10.1126/science.1259855 
52. Velki M, Hackenberger BK (2013) Biomarker responses in earthworm Eisenia andrei exposed to pirimiphos-methyl and deltamethrin using different toxicity tests. Chemosphere 90(3):1216-1226. https://doi. org/10.1016/j.chemosphere.2012.09.051

53. Velki M, Hackenberger BK (2013) Inhibition and recovery of molecular biomarkers of earthworm Eisenia andrei after exposure to organophosphate dimethoate. Soil Biol Biochem 57:100-108. https://doi. org/10.1016/j.soilbio.2012.09.018

54. Velki M, Lackmann C, Barranco A, Ereño Artabe A, Rainieri S, Hollert H, Seiler T-B (2019) Pesticides diazinon and diuron increase glutathione levels and affect multixenobiotic resistance activity and biomarker responses in zebrafish (Danio rerio) embryos and larvae. Environ Sci Eur 31(1):4. https://doi.org/10.1186/s12302-019-0186-0

55. Velki M, Meyer-Alert H, Seiler TB, Hollert H (2017) Enzymatic activity and gene expression changes in zebrafish embryos and larvae exposed to pesticides diazinon and diuron. Aquat Toxicol 193(October):187-200. https://doi.org/10.1016/j.aquatox.2017.10.019

56. Velki M, Weltmeyer A, Seiler TB, Hollert H (2019) Acute toxicities and effects on multixenobiotic resistance activity of eight pesticides to the earthworm Eisenia andrei. Environ Sci Pollut Res 26:4821-4832. https:// doi.org/10.1007/s11356-018-3959-x

57. Wang J, Wang J, Wang G, Zhu L, Wang J (2016) DNA damage and oxidative stress induced by imidacloprid exposure in the earthworm Eisenia fetida. Chemosphere 144:510-517. https://doi.org/10.1016/j.chemospher e.2015.09.004
58. Wang XH, Souders CL, Xavier P, Li XY, Yan B, Martyniuk CJ (2020) The pyrethroid esfenvalerate induces hypoactivity and decreases dopamine transporter expression in embryonic/larval zebrafish (Danio rerio). Chemosphere 243:125416. https://doi.org/10.1016/j.chemosphere.2019.125416

59. Wang Y, Cang T, Zhao X, Yu R, Chen L, Wu C, Wang Q (2012) Comparative acute toxicity of twenty-four insecticides to earthworm, Eisenia fetida. Ecotoxicol Environ Saf 79:122-128. https://doi.org/10.1016/j.ecoen v.2011.12.016

60. Ye X, Xiong K, Liu J (2016) Comparative toxicity and bioaccumulation of fenvalerate and esfenvalerate to earthworm Eisenia fetida. J Haza 310:82-88

61. Zhang Y, Shen G, Yu Y, Zhu H (2009) The hormetic effect of cadmium on the activity of antioxidant enzymes in the earthworm Eisenia fetida. Environ Pollut 157(11):3064-3068. https://doi.org/10.1016/j.envpo 1.2009.05.039

62. Zhang $Y$, Zhang L, Feng L, Mao L, Jiang H (2017) Oxidative stress of imidaclothiz on earthworm Eisenia fetida. Comp Biochem Physiol Part C 191:1-6. https://doi.org/10.1016/j.cbpc.2016.09.001

\section{Publisher's Note}

Springer Nature remains neutral with regard to jurisdictional claims in published maps and institutional affiliations. 